\title{
Consumer Citizenship Education for Sustainable Development in Higher Education in Latvia
}

\author{
Inese Jurgena \\ Riga Teacher and Educational Management Academy, Riga, Latvia \\ Zigurds Mikainis \\ University of Rezekne, Rezekne, Latvia
}

\begin{abstract}
Higher education and science determine the intellectual potential of a society, train new specialists, and consolidate and change citizenship values. Consumer citizenship education for sustainable development is an important function of higher education with a significant moral, social, political, economic, ecological and legal capacity. Consumer citizenship education plays an important role in ensuring the stability and sustainable development of any society. These approaches make it possible to develop the multi-scale thinking of future specialists and enhance their ability to analyse critically the main dilemmas created by the processes of social, legal, environmental, and economic development. The article is devoted to the experience of the Latvian system of higher education in consumer citizenship education within the context of sustainable development. It focuses more specifically on cooperation as a form of voluntary interaction between the partners involved in ensuring sustainable development. The aim of the research is to analyse the experience of consumer citizenship education in Latvian higher education within the context of sustainable development emphasizing the role of various forms of studies. Mostly theoretical research methods have been used in the present study. The starting point of for this research is a theoretical framework. There are both legal underpinnings and practical implementation aspects in this task. The features outlined above are emphasized in the normative acts referring to the Latvian higher education, the documents of the institutions of higher education, and particularly in the study programmes. The results of the research show that consumer citizenship education can be acquired as an interdisciplinary system. The goals and objectives of consumer citizenship education involve training young specialists possessing broad professional knowledge, developed critical thinking, the ability to organize and manage work in a modern way, understanding of the ethical, civic and patriotic values, as well as the ability and skills to engage in various social activities. Consumer citizenship education needs transdisciplinary knowledge if it is to solve the problems of humanity, the problems aggravated by unsustainable, unethical, even immoral consumption. The link between consumer citizenship education and sustainable development is ensured by shared common values, which reveal the sense and importance of both consumer citizenship and ethical sustainability.
\end{abstract}

Keywords: higher education, citizenship education, consumer citizenship education, sustainable development, consumer citizen

\footnotetext{
Inese Jurgena, Ph.D., Professor, Department of General Pedagogy, Riga Teacher Training and Educational Management Academy.

Zigurds Mikainis, Ph.D., Associate Professor, Department of the Humanities and Law, University of Rezekne.

Correspondence concerning this article should be addressed to Inese Jurgena, Imantas 7 linija 1, Riga, LV-1083, Latvia. E-mail: inese.jurgena@rpiva.lv.
} 


\section{Introduction}

Preparing citizens for the life in their own country, in the European Union, and in the world is a significant task of the system of higher education.

The United Nations Conference on Environment and Development (Rio de Janeiro, 1992) declared as its most important first principle that "human beings are at the centre of concerns for sustainable development. They are entitled to healthy and productive life in harmony with nature" (Retrieved from http://www.unesco.org/education/). This principle presumes that humans themselves are responsible for the conservation, protection, and care of the environment. This was a serious warning that the modern society is not sustainable, and the modern society is responsible for that.

The UN recognized the link between consumption, citizenship and sustainable development. The 1998 UN Human Development Report Overview was entitled, “Changing Today's Consumption Patterns-For Tomorrow’s Human Development” (Retrieved from http://hdr.undp.org/en/reports/global/hdr1998/).

The 1998 Report investigates the 20th century growth in consumption, unprecedented in its scale and diversity. The Report demonstrates that there is a need to strengthen public action for consumer education and information and environmental protection and to strengthen international mechanisms to manage the global impacts of consumption. The following Human Development Reports made room for a rich variety of information and analyses related to different aspects of human life.

After Johannesburg World Summit, the United Nations Economic and Social Council outlined educators' role as a key factor for sustainable development (Johannesburg World Summit on Sustainable Development, 2002). The 59th Session of the General Assembly of the United Nations in 2005 reaffirmed the need to ensure a balance between economic development, social development, and environmental protection as interdependent and mutually reinforcing pillars of sustainable development.

Besides, a considerable attention was devoted to it in the discussions concerning the development of knowledge-based society in Europe.

The importance of citizenship education was emphasized in the Bologna process (2000) where principal guidelines for higher education were determined. It is also an integral part of the European Strategy of Lifelong Learning and the European Youth Policy. It should be noted that the European Commission document a New Impulse for the European Youth (1991) highlighted new forms of the European governance based on youth autonomy and active participation of citizens, while the White Paper defined openness, participation, responsibility, effectiveness, and coordination as the principles of good democratic governance (White Paper, 1998).

The Council of Europe, consisting of 47 member states as of 2008, launched the curriculum development citizenship project “Education for Democratic Citizenship” in1997. In its third phase (2006-2009), the project aimed to promote education for democracy (EDC) and human rights education (HRE) with an emphasis on social cohesion, social inclusion, and respect for human rights ( Hahn Carole, 2010, p. 5).

Consumer citizenship is one such concept that has emerged in the contemporary world. Consumer citizenship can be seen as one important step in the process of sustainable development.

The concepts of "the citizen" and "the consumer" dominate major discourses on citizenship and consumption. There exist various approaches and discussions on the role of an individual as both a consumer and 
a citizen in the context of consumer citizenship (Devinney Timothy et al., 2010).

The benefits of citizenship education and the development and exercise of active citizenship can thus be seen as the ability to consider differing perspectives and divergent values from individual to group level, from local to global level, and to take action on political and ethical decisions that are often controversial. Active citizenship and citizenship education have often been seen as having the potential to empower individuals, to use opportunities to participate in public life at various levels, and to meet their civic obligations.

Consumer citizenship is an essential element of liberal education and is part of the on-going values debate, which institutions of higher education also participate in, to define the "quality of life". Consumer citizenship education encompasses knowledge and skills needed to become independent, critical and aware consumer citizens (Thoresen \& Guidelines, 2005, p. 11).

Thus, the actualization of consumer citizenship education is an important function of higher education with a significant moral, political, and legal capacity as it ensures the formation of the citizenship identity and consumer citizenship competency of would-be specialists within the context of sustainability.

In Latvia, the system of higher education, which undergoes continuous development, is one of the opportunities for introducing change. The potential of higher educational establishments, their resources and capacity in implementing educational reforms (UNESCO, 2005) ensure the development of an institution promoting sustainable development. Academic professionals striving to introduce changes play a key part there involving students in this process as well. Thus, reforms are promoted in a direct way, based on the experience of the participants, active cooperation, reflection, and formation of the new systems of reference.

The purpose of the article is to analyse the experience of consumer citizenship education in Latvian higher education within the context of sustainable development emphasizing the role of various forms of studies.

Mostly theoretical research methods have been used in the paper. The starting point for this paper is a theoretical framework.

The authors analyse theoretical sources, normative acts referring to the Latvian higher education, the documents of the institutions of higher education, and particularly the study programmes concerning the development of consumer citizenship education to get insight into higher education with regard to the sustainable development aspect.

\section{The Shared Values of Consumer Citizenship and Sustainable Development}

Generally, citizenship education is underpinned by the principle of rights, responsibilities, and participation within a democratic society. It is determined by the particular role of citizens and the specific importance of citizenship in the democratic society. Citizenship characterises the desirable actions of citizens referring to democracy as well as their citizenship virtues.

It has to be noted that the list of citizenship virtues is very extensive nowadays. Along with the readiness to participate actively in the social life and protect the democratic system of the state, it also includes readiness to call into question the actions of the authorities, to take part in discussing serious issues, to take into account opponents' views, to substantiate one's attitudes, and to respect other people's rights.

Active citizenship requires that individuals work to develop the community they live in through participation, volunteer work and efforts to improve life for all citizens. Consumer citizenship has a wide range of 
meanings: it is not merely about being an informed purchaser, but an active decision maker actively demanding consumer rights and responsibilities: curtailing the power of producers to exploit consumers, and to exploit workers and natural resources (Ross, 2008, p. 129-132).

Generally, the outcomes of consumer citizenship education could be defined as:

- Knowledge of one's rights and responsibilities as citizens, consumers and workers;

- Skills to function as informed and reflecting consumers citizens.

Socially responsible behaviour including:

- Critical awareness;

- Action and involvement;

- Social and ecological responsibility;

- Global solidarity (Thoresen, 2005, p. 26).

Similarly, education for consumer citizenship and sustainable development also includes responsibilities, rights, democratic practices and values, and understanding of the interdependence between all aspects of our societies.

There are rights and duties in the centre of the concept of consumer citizenship. The concept of the consumer citizenship demonstrates that consumers will act responsibly when obtaining goods and services for themselves. It includes assuming responsibility both in the global and regional, as well as the national and local level.

Responsibility is the pulse of human society. It is stimulated by vision, set in motion by awareness, realised through action and regulated by inner values, social norms, and/or legal criteria. There is no simple definition of responsibility. Responsibility is based on complex processes of initiatives, reactions, interventions and revisions. When considering the question of what constitutes consumer citizenship, it is necessary to first reflect upon the existing explanations of responsibility, subsequently to analyze the present distribution of responsibility, and then to contemplate which modifications appear necessary in order to contribute, individually and collectively, to more sustainable human development (Thoresen, 2005, p. 18).

Besides economic, political and ethical consciousness, education for consumer citizenship welcomes ecological consciousness (Hernandez, 2004). Thus, citizenship education for sustainable development (CESD) fosters competencies that are part of citizenship education, and it can be integrated into a wide range of curricula.

Clearly, consumer citizenship education plays an important role in ensuring the stability and sustainable development of any society.

Imbued in the notion of consumer citizenship are the various constructions of consumerism and various notions of citizenship. The scope of consumer citizenship has expanded greatly in recent years. Some researchers even argue that a clear distinction between citizen and consumer roles in public life is increasingly difficult to establish (Scammel, 2000). Consumer citizenship thus goes beyond "the rights of people to be provided with appropriate goods, services and information by both the private and public sectors” (Stevenson, 1997). It also includes social responsibility and the participation of citizens in the public sphere.

Consumption is presented not as an option, but as a duty and responsibility of consumer citizen (Zukin \& Maguire, 2004). Consumer citizenship education promotes active, rational, and responsible actions of young specialists and their participation in the implementation of democratic values.

Doubtless, an institution of higher education is an environment where it is possible to cognize, develop and 
promote critical, responsible, and responsive consumer citizenship. This should be particularly emphasized even if citizenship education is a highly contested and complex issue, difficult to define and fraught with difficulties (Bauer et al., 2003).

Kroflik (2004) argued that to prepare young people for life in social reality, citizenship education should be underpinned by the focus on the common core values of coexistence.

Values such as respect, honesty, self-esteem, trust, courage, and equity would be typical core values, which could be fostered in higher education through different courses. The transmission of such values presupposes a creative environment in the institution of higher education, based on the democratic decision-making processes and discussions.

Thus, it can be concluded that the link between citizenship education and education for sustainable development is ensured by the recognition of common values that promote both citizenship and ethical sustainability, focusing on the close link between various values, human life and the environment. From the perspective of sustainable development, there is a need to move from utilitarian and instrumental approaches and towards higher order values of respect and solidarity with the oneness of mankind and nature that supports ecosystems, equitable societies, and a more viable world.

In 1991, the World Conservation Union offered the content formulation of the values discussed above as the principles of sustainable living:

- Respect and care for the community of life;

- Improving the quality of human life;

- Conserving the earth's vitality and diversity;

- Minimising depletion of non-renewable resources;

- Keeping within the earth's carrying capacity;

- Changing personal attitudes and practices enabling communities to care for their own environments;

- Integrating development and conservation, creating a global alliance (Mulcahy \& Tutiaux-Guillon, 2005, p. 6).

These principles have an important role referring to the sustainable development of citizenship education.

An interesting complex diagram of the values of sustainable development has been offered in the academic literature (see Figure 1).

This diagram clearly suggests that sustainable development is a matter of political choice, and it comprises various social, legal, economic, and cultural elements.

Principle 10 of Agenda 21 also sets out that environmental issues are best handled with the participation of all concerned individuals, i.e., citizens have right to receive information on environmental issues and to have opportunities to participate in the decision-making process.

Throughout Agenda 21, there are also references to the eradication of poverty as an indispensible requirement for sustainable development. It underlines the need to achieve sustainable development and higher quality of life through the reduction and elimination of unsustainable patterns of production and consumption and through the promotion of appropriate demographic policies.

Obviously, the connection between values, human life and the environment is best revealed in the process how people use the environment, manage, protect, admire, worship, and respect it.

Hernandez (2004) points to values that can be developed through the study of citizenship and the 
environment from a scientific perspective. She distinguishes values involved in the search for information, specific values for environmental education, and personal values.

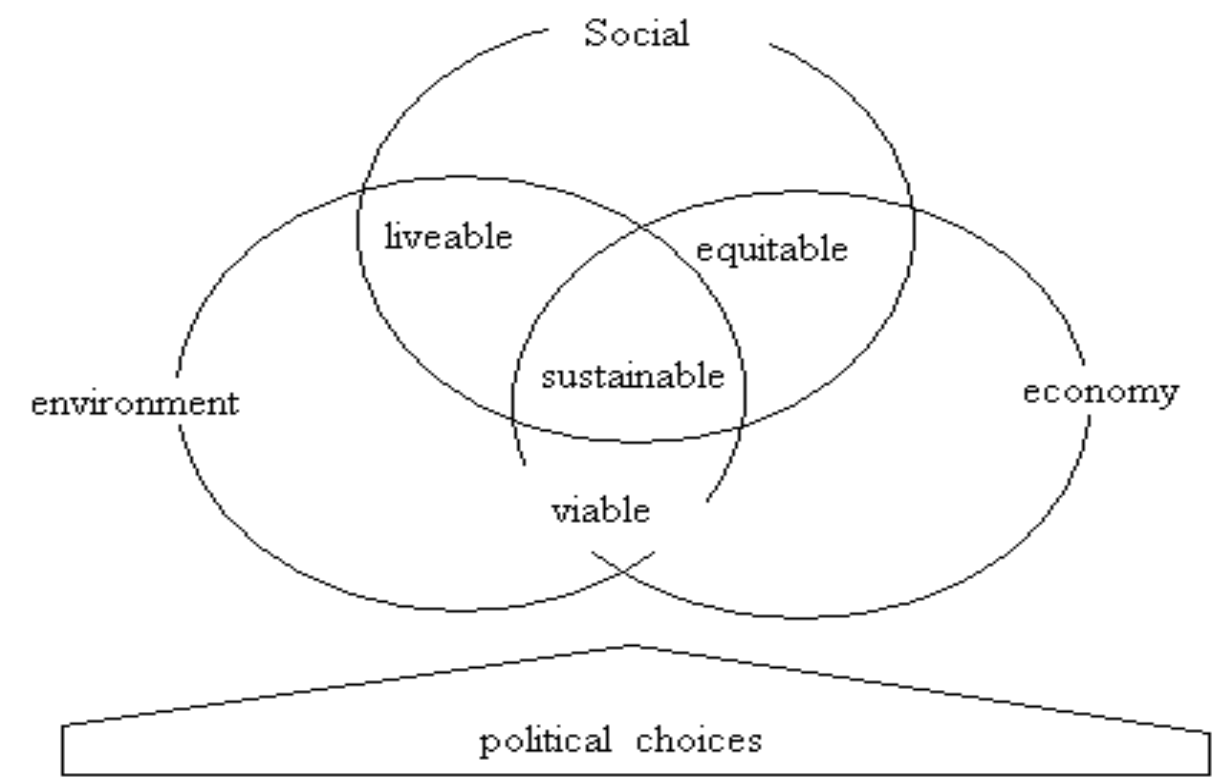

Figure 1. The complex diagram of the values of sustainable development (Mulcahi \& Tutiauks-Guillon, 2005, p. 5).

It has to be pointed out that it is even more important to ensure that the principles underpinning CESD were included in all courses of studies and could become an integral part of higher education.

Learning methodologies used in the process of studies should encourage the transmission of various core values through the creation of space for debate, discussion, sharing of ideas, creative problem-solving, working in teams, and thus developing critical thinking skills enabling future consumer citizens to live in the real environment away from the protection of the safety of the higher educational establishment.

In authors' view, in Latvia the practical integration of the above mentioned triad—knowledge, skills, and citizenship attitudes is shown most clearly in connection with the issues concerning the education of the teachers of social sciences.

A few issues concern the education of the teachers of social sciences in Latvia within the context of consumer citizenship education for sustainable development.

In Latvia, particular attention is devoted to the consumer citizenship education of the teachers of social sciences within the context of sustainability, their training for constructive cooperation both in the local and the European context. In the pedagogical aspect, the task of consumer citizenship education is to develop an active personality capable of functioning in a free civil society.

At present, the second level professional study programmes in teacher education have been designed according to the provisions of the Education Law, the Law on Higher Education Establishment, the Constitutions of higher educational establishments, and other normative acts, as well as the Regulations of the Cabinet of Ministers No. 347 "Regulations on the Requirements Concerning Teachers' Education and Professional Qualifications" and No. 481 "Regulations on the National Standard of the Second Level Professional Higher Education” (Retrieved from http://www.likumi.lv), and according to the Direction No. 405 of the Ministry of 
Education and Science of 10.07.2000 "On the Professional Standard-A Teacher of Social Sciences" (Professional Standard, 2002).

The purpose of the study programmes is to provide opportunities for the acquisition of professional higher education and obtaining the qualification of a teacher of social sciences, to train teachers for teaching social sciences at schools, thus ensuring their competitiveness in the labour market.

This can be ensured by offering a set of theoretical courses referring to social sciences-economics, ethics, health education, and consumer citizenship education. A particular attention is paid to the teaching methodology in social sciences and offering topical courses promoting students' professional development and enhancing their consumer citizenship competencies, as well as developing students' critical thinking skills and understanding of the diverse values necessary for living in a civil society with a good democratic political system.

There should also be provided opportunities for applying the acquired theoretical knowledge, skills, and professional attitudes in the pedagogical practice, involving students in tackling practical tasks (conducting classes, participation in projects, research, etc.).

As regards consumer citizenship education, in the recent years in Latvia, there has been more emphasis on motivating students for life-long learning, so that teachers themselves would be able to advance their knowledge in social sciences and evaluate new information and its correspondence to the requirements of modern science and the needs of the educational process within the context of active European citizenship.

When comparing the study programmes of the second level professional higher education offered in various institutions of higher education in Latvia — the University of Latvia (UL), Rezekne Higher Education Institution (RHEI), and Daugavpils University (DU), the course descriptions available in the accreditation documents of the Higher Education Quality Evaluation Centre (HEQEC), as well as the reports of the accreditation committees and self-evaluation reports were analysed (Retrieved from http://www.aiknc.lv).

It has to be noted, first of all, that courses concerning citizenship education and consumer education issues provided in the curricula of various institutions are different and unique. Generally, all these study programmes provide an opportunity to understand the basic elements of a democratic society and clarify what it means to be an active consumer citizen in a democratic environment within the context of sustainability.

The authors of the article have to note that there is no single best way how to integrate the content of consumer citizenship education for sustainable development in one particular course or study programme.

All in all, it can be concluded that the theoretical basis of professional education is formed in all teacher training programmes in social sciences by four important blocks:

- Citizenship education;

- Economic education;

- Ethical education;

- Health education.

Thus, the curricula offered in various institutions of higher education generally consolidate theoretical knowledge in economics, political science, philosophy, law, ethics, etc., helping students to combine their understanding of democracy with a democratic approach towards tackling the consumption issues as well.

It should be pointed out that integration of various kinds of knowledge and the versatility of knowledge within the framework of common vision is of particular importance. Consumer citizenship education needs 
transdisciplinary knowledge if it is to solve the problems of humanity, problems aggravated by unsustainable, unethical, even immoral consumption.

Such approach to consumer citizenship education regarding the aspect of sustainability also ensures its transversal role and interdisciplinary character.

Interrelationships in the content of core theoretical courses offered in the 2nd level professional higher education program “A Teacher of Social Sciences” can be seen in Figure 2.

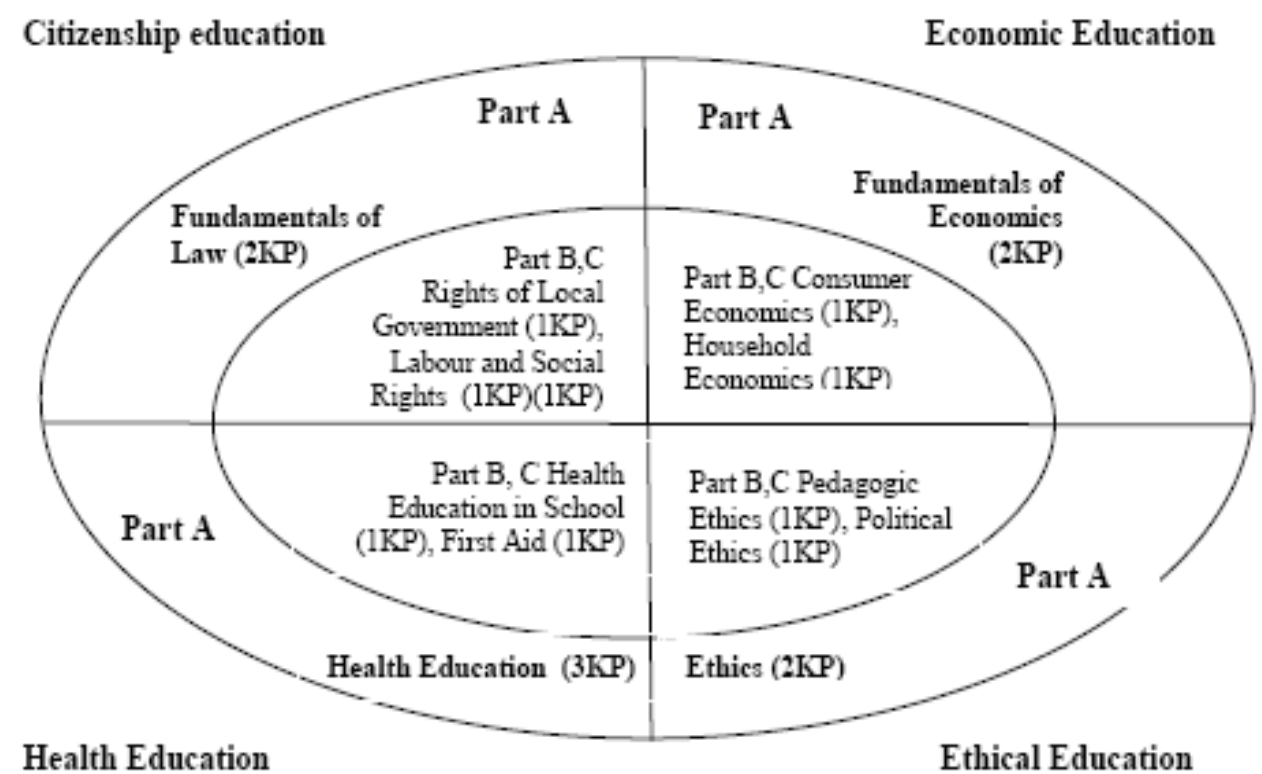

Figure 2. Interrelationships in the content of core theoretical courses offered in the 2nd level professional higher education program “A Teacher of Social Sciences” (RHEI accreditation Materials, www.aiknc.lv)

The accreditation materials available to the authors show that the forms of work and teaching methodologies used in the process of studies are not only the traditional ones: lectures, seminars, and practical classes, but also those which promote students' participation: project work, discussions, case studies, the analysis of documents, and research.

Students are encouraged to make public presentations concerning the results of their work, do self-evaluation, reflect on their own identity, express a critical attitude, and explain concepts.

Various courses include seminars aimed at the development of the skills of democratic cooperation, accepting or clarifying their point of view. Many of these techniques reflect the humanistic tradition in higher education. This approach is essential as the students need not only to be actively involved in their studies, but also to acquire methodologies which they will have to use when teaching social sciences at school.

The future teachers, both as citizens and educators, have to adapt and develop new approaches which will enable them to get involved reflectively and critically in the fundamental social transformations. Therefore, during the pedagogical practice, which takes place after the acquisition of basic theoretical courses, students can:

- Consolidate their skills in planning, organising, and assessing the integration between the educational content in social sciences and the process of upbringing;

- Learn the experience of a particular school and teacher, analyse topical problems, gain a deeper insight into the schools of various types, problems encountered by the teachers of social sciences and their solutions; 
- Consolidate skills necessary for integrated learning of social sciences and working in a team of teachers; gain understanding on the necessary areas of self-development and the possibilities to implement it.

Generally, it can be concluded that the acquisition of consumer citizenship education in various Latvian institutions of higher education takes place concurrently with the formation of the motivational attitude of students. While studying the offered courses, students acquire theoretical knowledge and practical skills, as well as realise their self-determination in accordance with the professional qualification of a teacher of social sciences.

The participants of the programme are focused on the acquisition and using of new teaching methodologies; however, insufficient level of material and technical provisions is a serious obstacle. It does not allow the academic staff and the students to fully use computer technologies, multimedia, and the internet, which would enhance the acquisition of the content of studies and its quality.

\section{Conclusions}

Consumer citizenship education plays a significant role in ensuring the stability and sustainable development of a society. It promotes the active position of young specialists and their rational and responsible participation in the implementation of democratic sustainable values.

Higher education ensures the intellectual potential of the society and trains new specialists, who develop and consolidate consumer citizenship values in the educational process.

Consumer citizenship education for sustainable development is an important function of higher education with a significant moral, social, political, and legal capacity. It promotes the consolidation of the principles and values of ethics, responsibility, law and participation in the democratic society.

Consumer citizenship education for sustainable development comprises fundamental values and understanding about the mutual dependence and interconnectedness of all aspects of social life. Consequently, it also ensures the formation of consumer citizenship competencies of future specialists.

In Latvia, consumer citizenship education can be acquired as an interdisciplinary system. This process is implemented in the context of changes and development, i.e., in a constructive context.

The analysis of the curricula offered by various institutions of higher education in Latvia shows that they provide most directly the development of the citizenship identity of future teachers of social sciences, the acquisition of the fundamental principles of a democratic society and the key values of the Latvian state and society, as well as the upbringing of competent young consumer citizens.

The Latvian experience shows that the goals and objectives of consumer citizenship education are focused on training young specialists possessing broad professional knowledge, developed critical thinking, ability to organise and manage work in a modern way, understanding of the ethical, civic and patriotic values, as well as ability and skills to engage in various social activities.

The link between consumer citizenship education and sustainable development is ensured by shared common values, which reveal the sense and importance of both consumer citizenship and ethical sustainability.

The assumption that various transversal and interdisciplinary approaches play a key role in consumer citizenship education of future specialists is offered for discussion. These approaches make it possible to develop the multi-scale thinking of future specialists and enhance their ability to analyse critically the main dilemmas created by the processes of social, legal, environmental, and economic development. 


\section{References}

20 Years of Global Human Development Reports. (2011). Retrieved March 15, 2011, from http://www.unesco.org/education; http://hdr.undp.org/en/reports/

Bauer, T., Clarke, M., \& Dailidiene, E. (2003). Active learning and citizenship education in Europe. London: CiCe, 1-24.

Devinney, T. M., Auger, P., \& Eckhardt, G. M. (2010). The myth of the ethical consumer (pp. 1-240). Cambridge University Press.

Education Law. (1998). Retrieved February 21, 2011, from http://www.likumi.lv/ doc.php?id=50759 (in Latvian).

Haav, K. (2009). Human rights and social sciences: Education for values understanding. Human rights and citizenship education (pp. 97-103). London: CICE.

Hahn, C. L. (2010). Comparative civic education research: What we know and what we need to know. Citizenship Teaching and Learning, 6(1), 5 -23.

Hernandez, A. J., \& Albillos, S. (2004). Citizenship education and environmental education today: Thoughts and proposals for its articulation. In A. Ross (Ed.), The experience of citizenship (pp. 140-144). London: CiCe.

Johannesburg World Summit on Sustainable Development. (2002). What is at stake? The contribution of scientists to the debate, Ministere des affaires entrangeres, direction de la cooperation scientique et de la recherché.

Kroflic, R. (2002). Education for democracy between formal law accession, ethical theories and pedagogical concepts. In A. Ross (Ed.), The experience of citizenship (pp. 140-144). London: CiCe.

Law on Higher Education Establishments. (1995). Retrieved February 21, 2011, from http://www.likumi.lv/doc. php?id=37967 (in Latvian).

Mulcahy, C., \& Tutiaux-Guillon, N. (2005). Guidelines on citizenship education for sustainable development (pp. 1-20). London, CiCe.

Professional Standard. (2002). Direction No. 405 of the Ministry of Education and Science of 10 June, 2002. Retrieved March 11, 2011, from http://www.likumi.lv/doc.php?id=8533\& (in Latvian).

RL Cabinet of Ministers Regulations No. 347. (2000). Regulations on the requirements concerning teachers' professional education and professional qualifications. Retrieved February 21, 2011, from http://www.likumi.lv/doc.php?id=11488 (in Latvian).

RL Cabinet of Ministers Regulations No. 481. (2001). Regulations on the national standard of the 2nd level professional higher education. Retrieved February 21, 2011, from from http://www.likumi.lv/doc.php?id=55887 (in Latvian).

Ross, A. (2008). A European Education citizenship, identities and young people. Trentham Books. Stoke on Trent, UK and Sterling USA, 129-132.

Scammel, S. (2000). The internet and civic engagement-The age of the citizen consumer. Political Communication, 17, 351-355.

Stevenson, N. (1997). Globalization, national cultures and cultural citizenship. The Sociological Quarterly, 38, 41-46.

Teacher of Social Sciences. $(2003,2006)$. Accreditation reports on the professional study programme of the second level. Retrieved February 21, 2011, from http://www.aiknc.lv/lv/list.php (in Latvian).

The 1998 UN Human Development Report. (1998). Retrieved February 22, 2011, from http://www.undp.org/hdro/hdrs/1998/english/ e98over.htm

The White Paper. (1998). On general and professional education. Teaching and learning towards the learning society. Brussels: Commission of European Community, November 29, 1995.

Thoresen, V. W. (2005a). Awareness, action and accountability. Taking responsibility. CCN conference proceedings (pp. 18-25). Bratislava.

Thoresen, V. W. (2005b). Consumer Citizenship Education Guidelines. Vol. 1, Higher Education. The Consumer Citizenship Network, 2005, p. 11.

UNESCO. (2005). Guidelines and recommendations for reorienting teacher education to address sustainability. Education for sustainable development in action. Technical Paper No. 2, October 2005.

Zukin, S., \& Maguire, S. (2004). Consumers and consumption. Annual Review of Sociology, 30. 